\title{
Pentingnya Badan Klasifikasi Kapal Dalam Industri Maritim
}

\author{
Santhi Wilastari \\ Politeknik Bumi Akpelni \\ Email: santhi@akpelni.ac.id
}

\begin{abstract}
ABSTRAK
Badan Klasifikasi Kapal adalah suatu usaha jasa yang berbeda dengan bidang industri lain. Dengan melihat kaitan dan peran sertanya dalam derap langkah industri maritim dan adanya aturan Klasifikasi Kapal yang dibuat sebagai acuan, maka hakikat adanya jasa pelayaran dari Badan Klasifikasi mempunyai latar belakang yang kuat untuk menunjang kemajuan industri maritim. Secara jelas, Biro Klasifikasi Kapal harus membuat dan menetapkan suatu standar atau tolak ukur, petunjuk- petunjuk atau rules untuk acuan dari perencanaan, konstruksi pembuatan, dan survei berkala dari kapal- kapal niaga dan bentuk konstruksi bangunan di laut lainnya. Sertifikat Class yang menunjukkan pada peraturan- peraturan dari rules tersebut akan menggambarkan kapal yang bersangkutan mempunyai kelayakan konstruksi dan mesin-mesinnya untuk digunakan sesuai dengan yang direncanakan. Dengan demikian suatu kapal yang dikelaskan akan memberikan keamanan terhadap kehidupan dan barang yang diangkut di kapal itu termasuk pencegahan pencemaran laut sekitarnya yang ditimbulkan dalam operasinya.
\end{abstract}

Kata Kunci: class, survei, Biro Klasifikasi

\section{PENDAHULUAN}

Sebelum kapal dapat diregister di Badan Klasifikasi Kapal, maka kapal tersebut harus memenuhi persyaratan dan peraturan teknik yang ada. Untuk kapal yang dibangun dengan persyaratan peraturan klasifikasi akan ditetapkan notasi kelas tersebut pada saat selesainya pemeriksaan secara keseluruhan melalui survei klasifikasi dengan nilai memuaskan. Untuk kapal yang sudah beroperasi, Badan Klasifikasi juga melaksanakan survei periodik untuk menjamin bahwa kapal masih memenuhi persyaratan klasifikasi tersebut.[1]

Semua pemeriksaan rutin dilakukan demi mencegah kecelakaan, menekan segala risiko berlayar, dan memastikan mesin kapal masih bekerja secara normal dan layak untuk melaut, dengan tujuan mengantarkan ribuan nyawa ke daratan dengan selamat.[5]

\section{METODE}

Kajian ini menggunakan pendekatan deskriptif. Metode pengumpulan data dengan studi pustaka untuk menggali informasi mengenai pentingnya peran Badan Klasifikasi.

\section{HASIL DAN PEMBAHASAN}

Klasifikasi kapal dilaksanakan berdasarkan pengertian bahwa kapal dimuati, dioperasikan dan dirawat dengan cara yang benar oleh awak kapal yang kompeten dan berkualitas. Pemilik kapal bertanggung jawab untuk menjamin bahwa perawatan kapal dilakukan dengan cara yang benar hingga survei periodik berikutnya sesuai persyaratan. Juga menjadi kewajiban pemilik kapal atau yang mewakilinya untuk menginformasikan kepada surveyor klasifikasi saat survei diatas kapal, semua kejadian atau kondisi yang berpengaruh terhadap status klasifikasi. 
Bila kondisi mempertahankan klasifikasi tidak terpenuhi, maka Badan Klasifikasi akan menangguhkan (suspend) atau (withdraw) status klasifikasinya berdasarkan referensi persyaratan klasifikasi. Kapal mungkin akan kehilangan status klasifikasinya untuk sementara atau permanen. Demikian juga kapal yang tidak melaksanakan survei secara periodik tepat waktu sesuai dengan peraturan klasifikasi, maka Badan Klasifikasi akan menangguhkan (suspend) status klasifikasinya. Badan Klasifikasi dalam melaksanakan survei meliputi [1]:

1. Keseluruhan pemeriksaan item survei sesuai dengan daftar isian yang di desain sesuai dengan persyaratan klasifikasi.

2. Pemeriksaan yang lebih mendetail bagian- bagian tertentu kapal

3. Menyaksikan (witness), proses pengujian (testing), pengukuran (measurement), dan percobaan (trial) untuk meyakinkan pemenuhan terhadap persyaratan klasifikasi.

IACS (International Association of Classification Societies) adalah suatu organisasi assosiasi yang beranggotakan badan-badan klasifikasi dunia yang dibentuk pada tahun 1968, yang secara obyektif mengutamakan standar tertinggi dalam keamanan kapal dan pencegahan terhadap pencemaran laut. Assosiasi mempunyai peranan penting dalam memberikan saran- saran dalam dunia perkapalan. Lebih dari $90 \%$ jumlah tonnage dari kapal- kapal niaga seluruh dunia dikelaskan kepada assosiasi. Dalam pengertian terhadap konstruksi lambungnya, mesin-mesin dan sistem utamanya yang selalu diperiksa dan dimonitor secara terus menerus.

Dalam keterkaitannya untuk selalu berperan memajukan dan memperbaiki standar keamanan kapal dengan pencegahan pencemaran laut, maka assosiasi selalu mengadakan konsultasi dan bekerja sama dengan International Maritime Organization
(IMO), juga dengan memupuk kerjasama yang erat dengan dunia industri maritim dan organisasiorganisasi internasional lainnya seperti International Chamber of Shipping, Oil Companies International Marine Forum, Society of International Gas Tanker and Terminal Operator Limited.

Seperti yang telah dirintis sejak 1930, pada masa- masa selanjutnya tugas Badan Klasifikasi sebagai pendiri IACS menginginkan suatu keseragaman dalam beberapa technical standart khusus terutama mengenai ketetapan aturan dan interprestasi terhadap konvensikonvensi internasional dan codes. Keseragaman ketetapan- ketetapan yang telah dibuat [4]: Minimum longitudinal standart strengths standart; Enchanced hull surveys for farious hull members; Use of steel grades for various hull members; Hull and machinery steel casting; Cargo containment on gas tankers; Prototype testing and test measurement in tank containers; Inert gas generating installation on vessels carrying oil; Fire protection of machinery spaces; Hatchway of hatch covers and coaming; Various requirements on diesel engine and propeller shafting.

Asosiasi membentuk kelompokkelompok kerja (working group) yang secara khusus dan terus menerus menangani aturan-aturan untuk menghadapi perkembangan teknologi kelautan.

Topik yang telah digarap secara bersama[4]: Containers, Drilling Units, Electricity, Engines, Fire Protection, Gas and Chemical Tangkers, Hull Damage, Island Water Way Vessels, Marine Pollution, Material and Welding, Mooring and Anchoring, Pipes and Pressure Vessels, Strength of Ships, Subdivision, Stability and Load line, Survey, Reporting and Certification.

Anggota utama dari Assosiasi Badan Klasifikasi Kapal (IACS membership) adalah: Biro Klasifikasi Indonesia (BKI), America Bereau of 
Shipping (ABS), Bereau Veritas $(B V)$, China Classification Society (ZC), Det Norske Veritas (DNV), Germanische Lloyd (GL), Korea Register of Shipping (KR), Lloyd Register of Shipping (LR), Nippon Kaiji Kyokai (NKK), Polski Register Statkow, Registro Italiano Navale (RINA), Register of Shipping (RUSSIA), Croation Register of Shipping, dan Indian Register of Shipping.

Asosiasi menetapkan suatu Quality System Certication Scheme (QSCS) untuk menjadikan dan menjaga reputasi anggota assosiasi sebagai suatu badan yang selalu konsisten dengan standar tinggi dan berintegritas yang terjaga.

Pemikiran kualitas dari anggotaanggota assosiasi mencakup kegiatan: 1) Klasifikasi kapal-kapal dan bangunan anjungan lepas pantai berkenaan dengan perencanaan konstruksi pembuatan dan pengopersiannya; 2) Statutory survey yang dikerjakan atas limpahan wewenang yang diberikan oleh administrasi negara yang bersangkutan (lebih dari 100 negara di dunia memberi wewenang kepada anggota-anggota assosiasi untuk melaksanakan survei dari bermacam jenis, statutory yang diwakilkan antara lain berkenaan dengan Load Line, SOLAS, dan MARPOL, pengukuran tonnage serta IMO codes lainnya.

Keuntungan utama terhadap pemilik kapal adalah keseluruhannya telah terdaftar jajaran kapal yang harus dilayani oleh suatu Badan Klasifikasi Internasional yang member adanya jaminan terhadap suatu standart atau rules yang telah diterima secara internasional. Beberapa keuntungan lainnya berkenaan dengan dipertahankannya klasifikasi kapal tersebut antara lain [3]:

1. Tujuan Asuransi

Aspek utama yang penting dari kapal yang dikelaskan adalah merupakan syarat penting untuk jaminan asuransi terhadap lambung kapal dan muatannya.
Klaim asuransi yang dibayar biasanya tergantung juga dari pembuktian pemilik kapal bahwa kelas dari kapalnya tetap berlaku pada waktu kecelakaan.

2. Tujuan pencharteran

Pada waktu pencharteran suatu kapal, biasanya pencharter ingin kapal tersebut dalam keadaan kelas dipertahankan. Selama bare boat charter pemilik kapal biasanya tidak menginginkan pihak pencharter menunda survei dalam mempertahankan kelas kapal selama waktu pencharteran.

3. Penjualan kapal

Dokumen-dokumen klasifikasi biasanya merupakan surat pertama dari kapal yang di minta oleh calon pembeli dalam proses penjualan kapal. Dalam beberapa hal ternyata record dan arsip laporan kelas merupakan berkas riwayat kapal bagi calon pembeli.

Pada waktu penjualan kapal disetujui, biasanya pembeli meminta suatu sertifikat konfirmasi kelas yang merupakan bukti bahwa survei telah dikerjakan dan tidak ada rekomendasi yang terhutang, seperti kerusakan yang masih belum dikerjakan atau reparasi yang belum diperiksa dan disetujui oleh kelas.

4. Keuangan

Konfirmasi bahwa sebuah kapal telah dibuat atau sedang dibuat berdasarkan suatu standar atau rules dari suatu badan klasifikasi yang dikenal selalu merupakan suatu syarat yang diminta oleh bank atau instansi keuangan lainnya. Secara umum kapal yang dikelaskan mempunyai nilai jual yang lebih baik.

5. Bukti pemeliharaan yang rutin dan rajin

Klasifikasi dapat memberikan bukti bahwa pemilik kapal telah melaksanakan pemeliharaan kapal yang rutin dan baik atas jaminan kondisi konstruksi dan mesin, dengan demikian akan memperkecil kemungkinan penyebab terjadinya kerusakan

6. Survei Sertifikat Statutory 
Kurang lebih 100 negara di dunia melimpahkan wewenang kepada Badan Klasifikasi untuk melakukan survei dan pengeluaran sertifikat Load Line, MARPOL, Tonnage dan beberapa sertifikat statutory lainnya. Peranan dari Klasifikasi dalam hal ini menjadi hal yang penting dalam dunia industri perkapalan karena kenyataannya banyak negara tahu pemerintah yang bersangkutan kekurangan tenaga untuk melaksanakan pemeriksaan terhadap gambar teknik dan survei yang diperlukan dalam rangka pengeluaran sertifikat secara internasional.

7. Registrasi

Beberapa negara atau pemerintah menyebutkan klasifikasi sebagai badan yang dikenal secara internasional menjadi suatu ketentuan dalam proses registrasi bendera suatu kapal niaga.

8. Pengeluaran registrasi alat angkat atau crane

Meskipun hal ini bukan merupakan kondisi kelas Registrasi Cargo Gear atau Registrasi Crane untuk Mobile Offshore Drilling Unit dapat dikeluarkan atas permintaan pemilik kapal sesudah dilakukan pemeriksaan rancang bangunnya dan survei oleh Badan Klasifikasi. Biasanya registrasi tersebut merupakan syarat untuk memenuhi standar ILO (organisani buruh dunia) dan prakteknya selalu dibutuhkan di semua pelabuhan sebelum diijinkan bongkar muat.

\section{SIMPULAN.}

Badan Klasifikasi Kapal memiliki peran penting dalam rules administrasi, statutory service, research and development, dan technical advisory service. Badan Klasifikasi harus membuat suatu standar, petunjuk dan peraturan untuk perencanaan konstruksi survei untuk kapal dan bangunan di laut lainnya seperti Mobile Offshore Drilling Unit.

Badan Klasifikasi Kapal
berperan melakukan pemeriksaan
terhadap gambar teknik dan survei yang diperlukan dalam rangka pengeluaran sertifikat secara internasional. Juga tidak lepas dari aktifitas survei untuk bangunan kapal baru, pemeriksaan dan sertifikasi dari material dan kapal lainnya.

Research and Development secara terus menerus harus dikerjakan oleh Badan Klasifikasi untuk meningkatkan dalam konstruksi kapal, pemeliharaannya, pengoperasiannya, sistem komunikasi, dan navigasi, yang penting sekali untuk pengembangan rules yang merupakan standar yang diakui

Dalam bidang technical advisory service, Badan Klasifikasi diminta selalu mengembangkan pelayanannya untuk kepentingan kemajuan industri maritim. Badan Klasifikasi dengan semua instansi dari pemerintah, professional group, pemilik kapal, galangan kapal, dan perusahaan lain yang berkecimpung dalam dunia maritim, secara bersamasama ikut menciptakan keamanan jiwa, hak milik dan pencegahan pencemaran di lautan.

\section{DAFTAR PUSTAKA}

[1].Syakip Darmawan, Klasifikasi Mempromosikan Jaminan Keselamatan Jiwa, Harta Benda dan Lingkungan, ABS, Jakarta, 1997

[2].www.abs.com

[3].www.bki.co.id

[4].www.IACS.com

[5].http://www.bumn.go.id/bki/berita/65 